\title{
Toksisitas Akut Ekstrak Air Buah Pepaya (Carica papaya L.) Muda terhadap Morfologi Eritrosit
}

\author{
Yuktiana Kharisma, ${ }^{1}$ Eka Hendryanny, ${ }^{2}$ Astari P. Riani ${ }^{3}$ \\ ${ }^{1}$ Bagian Farmakologi, ${ }^{2}$ Bagian Fisiologi, ${ }^{3}$ Fakultas Kedokteran, Universitas Islam Bandung, Bandung
}

\begin{abstract}
Abstrak
Pepaya (Carica papaya L.) adalah salah satu obat tradisional yang digunakan untuk mengatasi masalah kesehatan. Pepaya mengandung beberapa substansi fitokimia seperti saponin, alkaloid, terpenoid, dan flavonoid. Saponin dan alkaloid diketahui mampu berinteraksi dengan membran eritrosit dan menyebabkan disintegrasi membran sehingga dapat menyebabkan kerusakan pada eritrosit. Penelitian ini bertujuan mengetahui toksisitas akut ekstrak air buah pepaya muda terhadap morfologi eritrosit melalui pengamatan sediaan apus darah tepi. Metode penelitian ini adalah eksperimental laboratorium dilakukan di Laboratorium Biomedis, Fakultas Kedokteran, Universitas Islam Bandung periode Januari-Februari 2016. Penentuan kelompok dosis berdasar atas proposed (new) recommended method menggunakan 11 ekor tikus yang diberi dosis oral ekstrak air buah pepaya muda 50, 200, 400, 800, 1.000, 1.500, 2.000, 3.000, 4.000, 5.000 mg/kgBB masing-masing dan satu tikus hanya diberikan air sebagai kelompok kontrol. Pengamatan dilakukan setelah 24 jam pemberian ekstrak. Hasil pengamatan sediaan apus darah tepi menunjukkan tidak terdapat perubahan morfologi eritrosit baik bentuk, ukuran, dan warnanya. Simpulan, ekstrak air buah pepaya muda tidak memiliki toksisitas akut terhadap morfologi eritrosit.
\end{abstract}

Kata kunci: Buah pepaya muda, eritrosit, toksisitas akut

\section{Acute Toxicity of Unripe Papaya Fruit (Carica papaya L.) Water Extract to Morphology of Erythrocyte}

\begin{abstract}
Papaya (Carica papaya L.) is one of traditional medicines which was used to overcome health things. It is contained of some phytochemicals substance such as saponin, alkaloid, terpenoid, and flavonoid. Both saponin and alkaloid were known having an ability to interract with eryhtrocyte membran and cause membrane disintegrity that can destruct the erythrocyte. This study was aimed to know the acute toxicity of the aqueous extract of unripe papaya fruit to the erythrocyte morphology by observe the peripheral blood smear. The method of this study was conducted experimental laboratory at Loboratory of Biomedical, Faculty of Medicine, Universitas Islam Bandung in JanuaryFebruary 2016. Determination of dose group is based on proposed (new) recommended method with 11 rats were administrated oral dose 50, 200, 400, 800, 1,000, 1,500, 2,000, 3,000, 4,000, 5,000 mg/kgBW of unripe papaya fruit aqueous extract, and one rat was only given water as control group. Observation had been done at 24 hours after extract administrating. It showed that there was not any abnormal morphology, size, and chromatic changes of erythrocyte in blood smear observations. In conclusion, the aqueous extract of unripe papaya fruit do not have the acute toxicity to erythrocyte morphology.
\end{abstract}

Key words: Acute toxicity, erythrocyte, unripe papaya

Korespondensi: Yuktiana Kharisma. Bagian Farmakologi, Fakultas Kedokteran, Universitas Islam Bandung. Jln. Tamansari No. 22, Bandung, Jawa Barat, Indonesia, 40116. HP: +6287821360031. E-mail: yuktiana@gmail.com 


\section{Pendahuluan}

Indonesia merupakan negara yang kaya bahan alam, khususnya tanaman obat (herbal), yaitu sekitar 25.000 sampai 30.000 spesies tanaman. Sebanyak 7.000 spesies tanaman di Indonesia digunakan oleh masyarakat sebagai obat dan 283 spesies tanaman yang telah didaftarkan ke Badan Pengawas Obat dan Makanan (BPOM). ${ }^{1}$ Penggunaan obat herbal melalui pemanfatan bahan-bahan alam sudah menjadi tradisi yang turun temurun. ${ }^{2}$ Penggunaan obat tradisional di Indonesia semakin meningkat. Beberapa obat tradisional yang dipergunakan oleh masyarakat antara lain adalah buah mahkota dewa (Phaleria macrocarpa), buah kemukus (Piper cubeba), buah mengkudu (Morinda citrifolia), dan buah pepaya (Carica papaya L.). ${ }^{3}$

Tanaman pepaya (Carica papaya L.) adalah merupakan jenis tanaman tropis. Hampir seluruh bagian tanaman pepaya seperti daun, akar, buah, dan biji dapat digunakan sebagai obat tradisional. Buah pepaya mengandung nutrisi (vitamin A, vitamin $\mathrm{B}$, vitamin $\mathrm{C}$, zat besi, natrium, kalsium, kalium), enzim (papain, chymopapain, carpain, lycopene), dan senyawa aktif lainnya (saponin, flavonoid, alkaloid, serta terpenoid). Berdasarkan atas penelitian buah pepaya muda diketahui mengandung lebih banyak nutrisi dan metabolit sekunder dibanding dengan pepaya yang telah matang. ${ }^{4}$

Senyawa yang aktif dalam buah pepaya dapat memberikan beberapa manfaat jika digunakan dalam dosis yang sesuai, seperti alkaloid, saponin, dan flavonoid juga memiliki efek antibakterial, antioksidan, serta anti-inflamasi. Alkaloid dan saponin diketahui dapat meningkatkan produksi ASI (laktagogum). ${ }^{5,6}$ Akan tetapi, pemanfaatan buah pepaya tersebut yang tidak sesuai dapat menimbulkan dampak merugikan. Saponin dan alkaloid berinteraksi dengan struktur seluler aktif seperti eritrosit sehingga dapat menyebabkan disintegrasi membrannya yang mengakibatkan hemolisis. 7,8

Pengembangan penelitian tanaman tentang obat dilaksanakan agar tanaman obat tersebut dapat dimanfaatkan untuk pengobatan manusia sehingga uji toksisitas sebagai uji praklinis sangat diperlukan untuk mengetahui tingkat keamanan tanaman obat dan efek samping yang mungkin dapat ditimbulkan. ${ }^{9}$

Aktivitas hemolisis dapat diukur baik secara langsung dengan melihat peningkatan destruksi eritrosit maupun secara tidak langsung dengan mengamati sediaan apus darah tepi eritrosit melalui penentuan ukuran, bentuk, distribusi, dan warna eritrosit. Pengamatan lain dilakukan terhadap variasi ukuran sel-sel eritrosit berupa apakah normositer, makrositer, atau mikrositer. Bentuk bulat eritrosit normal dapat mengalami perubahan menjadi sel target seperti spherocytes, stomatocytes, ovalocytes, elliptocytes, dan sickle cell. Variasi warna yang terlihat pada eritrosit dapat berupa normokrom, hipokrom, hiperkrom, dan polikromasia. Aktivitas hemolisis yang tinggi mampu menyebabkan gambaran eritrosit tidak matur (normoblas) pada sediaan apus darah tepi akibat peningkatan produksi eritrosit. ${ }^{10}$

Pengembangan penelitian mengenai tanaman obat seperti uji toksisitas dilakukan agar tanaman obat itu dapat dimanfaatkan untuk pengobatan manusia dengan aman. Salah satu uji toksisitas tersebut adalah uji toksisitas akut, yaitu uji untuk mengidentifikasi efek yang tidak diinginkan pada interval waktu yang singkat setelah pemberian satu atau beberapa zat dalam 24 jam. Efek yang merugikan tersebut di atas akan mengakibatkan gangguan fungsional pada organ dan sel. ${ }^{11}$

Penilaian $\mathrm{LD}_{50}$ (dosis yang membunuh $50 \%$ populasi hewan uji) kini telah digunakan sebagai parameter utama untuk mengukur toksisitas akut dan juga sebagai prosedur awal skrining umum. Berdasar atas penelitian yang telah dilakukan menggunakan metode Karber diketahui $\mathrm{LD}_{50}$ dari ekstrak air buah pepaya (Carica papaya L.) muda pada uji toksisitas akut sebesar 2,520 mg/kgBB. Pada penelitian yang dilakukan oleh Nadiyah dkk. ${ }^{12}$ menyatakan bahwa $\mathrm{LD}_{50}$ dari ekstrak air buah pepaya (Carica papaya L.) muda diperoleh $>5,000 \mathrm{mg} / \mathrm{kgBB}$.

Tujuan penelitian ini mengetahui toksisitas akut ekstrak air buah pepaya (Carica papaya L.) muda terhadap morfologi eritrosit pada tikus putih (Rattus norvegicus) galur Wistar melalui pengamatan sediaan apus darah tepi.

\section{Metode}

Penelitian ini menggunakan desain eksperimental murni in vivo dengan rancangan acak lengkap pada 12 ekor tikus putih galur Wistar (Rattus norvegicus) sebagai subjek penelitian ini. Bahan penelitian berupa buah pepaya muda varietas Paris yang tidak dikupas (termasuk biji) dengan umur buah sekitar 2,5-3 bulan, buah keras padat, kulit buah berwarna hijau, dan biji berwarna putih. Buah pepaya itu berasal dari perkebunan pepaya di Kecamatan Leles, Kabupaten Garut, 


\section{Tabel 1 Kandungan Fitokimia Ekstrak Air Buah Pepaya (Carica papaya L.) Secara Kualitatif}

\begin{tabular}{llcl}
\hline Senyawa & Reaksi & Hasil Uji* & Keterangan \\
\hline Flavonoid & Sampel+Mg+HCl+amil alkohol & + & Terbentuk warna merah bata \\
Terpenoid & Sampel+eter $+\mathrm{H}_{2} \mathrm{So}_{4}+$ asam asetat glasial & + & Terbentuk warna merah, ungu, hitam \\
Alkaloid & Sampel+dragendrof $+\mathrm{CHCl}_{3}+\mathrm{HCl}$ & + & Terbentuk warna jingga \\
Saponin & Sampel+HCl (kocok) & + & Terbentuk busa \\
\hline
\end{tabular}

*Keterangan: +: terdapat kandungan senyawa kimia dalam ekstrak

Jawa Barat. Buah pepaya muda dibuat dalam bentuk sediaan ekstrak memakai pelarut air. Ekstrak air buah pepaya muda itu kemudian diperiksa kandungan kimianya melalui penapisan fitokimia secara kualitatif (Tabel 1). Penelitian dilakukan di Laboratorium Biomedis, Fakultas Kedokteran, Universitas Islam Bandung (Unisba) pada Januari-Februari 2016.

Besar sampel penelitian ini merujuk terhadap prosedur untuk menentukan toksisitas akut yang telah dipublikasikan Toxicology International Journal ${ }^{11}$ menggunakan metode proposed (new) recommended method. Metode ini terdiri atas beberapa tahapan yang meliputi tiga tahapan uji toksisitas dan satu tahapan uji konfirmasi.

Penelitian ini dimulai dengan tahap pertama mempergunakan 4 kelompok percobaan, tiaptiap kelompok menggunakan 1 ekor tikus dengan dosis $50 \mathrm{mg} / \mathrm{kgBB}$ per oral (p.o.), $200 \mathrm{mg} / \mathrm{kgBB}$ p.o., $400 \mathrm{mg} / \mathrm{kgBB}$ p.o., dan juga $800 \mathrm{mg} / \mathrm{kgBB}$ p.o. Tahap kedua mempergunakan 3 kelompok percobaan yang terdiri atas 1 ekor tikus tiap kelompok dengan dosis $1.000 \mathrm{mg} / \mathrm{kgBB}$ p.o., $1.500 \mathrm{mg} / \mathrm{kgBB}$ p.o., dan juga $2.000 \mathrm{mg} / \mathrm{kgBB}$ p.o. Tahap ketiga mempergunakan 3 kelompok percobaan dengan kelompok terdiri atas 1 ekor tikus yang diberikan sediaan ekstrak dengan dosis $3.000 \mathrm{mg} / \mathrm{kgBB}$ p.o., $4.000 \mathrm{mg} / \mathrm{kgBB}$ p.o., dan $5.000 \mathrm{mg} / \mathrm{kgBB}$ p.o. Apabila menemukan subjek penelitian yang mati maka dilakukan uji konfirmasi mempergunakan 2 ekor tikus yang diberikan dosis paling rendah yang menyebabkan kematian. ${ }^{11}$

Subjek penelitian diamati selama 24 jam, kemudian darah dari bagian ekor tikus sebanyak 0,5 $\mathrm{mL}$ ditampung dalam tabung penyimpanan darah yang mengandung ethylene diamamina tetra acetic acid atau EDTA untuk menghindari penggumpalan darah. Sesudah itu, sampel darah subjek penelitian dibuat menjadi sediaan apus darah tepi (SADT) pada gelas objek dan diwarnai dengan pewarnaan Giemsa.

Pengamatan morfologi sel darah tepi tersebut mempergunakan mikroskop cahaya pembesaran lensa objektif 100× yang dibantu dengan cara meneteskan minyak emersi pada gelas objek. Pengamatan terhadap morfologi darah dilakukan dengan menentukan berbagai perubahan eritrosit meliputi perubahan ukuran, bentuk, dan warna.

Sediaan apus darah tepi dengan gambaran eritrosit yang terdistribusi secara merata dan layak dinilai pada pembesaran lensa objektif 10×, kemudian diamati dengan mempergunakan pembesaran 100×. Setiap kelompok dilakukan pengamatan pada 5 lapang pandang.

\section{Hasil}

Hasil pengamatan sediaan apus darah tepi untuk melihat variasi ukuran eritrosit yang tersaji pada Gambar menunjukkan gambaran eritrosit normositer pada semua kelompok perlakuan dan kontrol. Pengamatan variasi warna pada sediaan apus darah tepi menunjukkan gambaran eritrosit dengan central pallor $1 / 3$ ukuran sel yang berarti eritrosit normokrom. Bentuk sel eritrosit bulat ditemukan pada kelompok dosis 50, 200, 800, 1.000, 1.500, 2.000, 3.000, 4.000, $5.000 \mathrm{mg} /$ kgBB menunjukkan sel eritrosit pada kelompokkelompok dosis tersebut mempunyai bentuk yang normal. Pada kelompok dosis $400 \mathrm{mg} / \mathrm{kgBB}$ secara umum ditemukan bentuk eritrosit bulat dan terdapat satu bentuk eritrosit tear drop. Akan tetapi, variasi bentuk yang ditemukan $<5 \%$ sehingga kelompok dosis $400 \mathrm{mg} / \mathrm{kgBB}$ masih tergolong normal.

Hasil dari penelitian ini secara keseluruhan menunjukkan pada pengamatan sediaan apus darah tepi tidak ditemukan perubahan morfologi eritrosit baik ukuran, bentuk maupun warna pada setiap kelompok dosis perlakuan dan kontrol. 

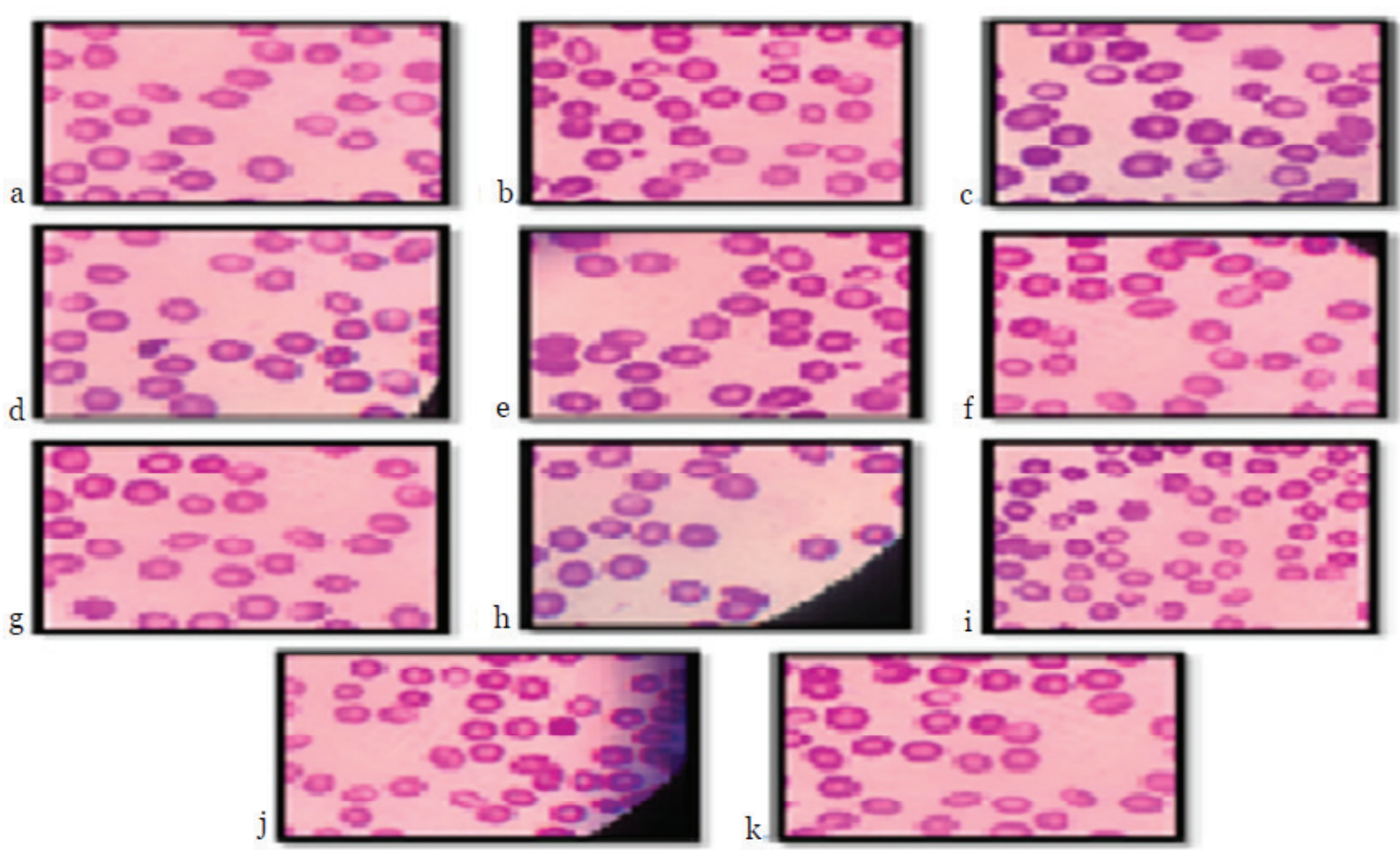

Gambar Ukuran, Warna, dan Bentuk Eritrosit pada Sediaan Apus Darah Tepi

a. kontrol, b. dosis $50 \mathrm{mg} / \mathrm{kgBB}$ p.o., c. dosis $200 \mathrm{mg} / \mathrm{kgBB}$ p.o., d. dosis $400 \mathrm{mg} / \mathrm{kgBB}$ p.o., e. dosis $800 \mathrm{mg} / \mathrm{kgBB}$ p.o., f. dosis $1.000 \mathrm{mg} / \mathrm{kgBB}$ p.o., g. dosis $1.500 \mathrm{mg} / \mathrm{kgBB}$ p.o., h. dosis $2.000 \mathrm{mg} /$ $\mathrm{kgBB}$ p.o., i. dosis 3.000 mg/kgBB p.o., j. dosis $4.000 \mathrm{mg} / \mathrm{kgBB}$ p.o., k. dosis 5.000 mg/kgBB p.o.

\section{Pembahasan}

Berdasar atas hasil skrining fitokimia ekstrak air buah pepaya (Carica papaya L.) muda yang digunakan dalam penelitian memiliki kandungan flavanoid, terpenoid, alkaloid, dan saponin (Tabel 1).

Alkaloid adalah senyawa yang mengandung atom nitrogen dan memiliki fungsi dalam bidang pengobatan. Akan tetapi, pada penelitian isolasi

Tabel 2 Hasil Pengamatan Bentuk Eritrosit pada Sediaan Apus Darah Tepi

\begin{tabular}{cccccccccc}
\hline \multirow{2}{*}{ Tikus } & $\begin{array}{c}\text { Dosis p.o. } \\
(\mathbf{m g} / \mathbf{k g B B})\end{array}$ & \multicolumn{10}{c}{ Bentuk Eritrosit } \\
\cline { 3 - 10 } & & Normal & $\begin{array}{c}\text { Target } \\
\text { cell }\end{array}$ & $\begin{array}{c}\text { Sphero- } \\
\text { cytes }\end{array}$ & $\begin{array}{c}\text { Stomato- } \\
\text { cytes }\end{array}$ & $\begin{array}{c}\text { Ovalo- } \\
\text { cytes }\end{array}$ & $\begin{array}{c}\text { Ellipto- } \\
\text { cytes }\end{array}$ & $\begin{array}{c}\text { Sickle } \\
\text { cell }\end{array}$ & $\begin{array}{c}\text { Burr } \\
\text { cell }\end{array}$ \\
\hline -Kontrol & & + & - & - & - & - & - & - & \\
-Kelompok & 50 & + & - & - & - & - & - & - & - \\
percobaan & 200 & + & - & - & - & - & - & - & - \\
& 400 & + & - & - & - & - & - & - & - \\
& 800 & + & - & - & - & - & - & - & - \\
& 1.000 & + & - & - & - & - & - & - & - \\
& 1.500 & + & - & - & - & - & - & - & - \\
& 2.000 & + & - & - & - & - & - & - & - \\
& 3.000 & + & - & - & - & - & - & - & - \\
& 4.000 & + & - & - & - & - & - & - & - \\
& 5.000 & + & - & - & - & - & - & - & - \\
\hline
\end{tabular}


Tabel 3 Hasil Pengamatan Variasi Ukuran Eritrosit pada Sediaan Apus Darah Tepi

\begin{tabular}{lrrcr}
\hline \multirow{2}{*}{ Tikus } & Dosis p.o. & \multicolumn{3}{c}{ Variasi Ukuran } \\
\cline { 3 - 5 } & (mg/kgBB) & Normositer & Makrositer & Mikrositer \\
\hline - Kontrol & & + & - & - \\
- Kelompok & 50 & + & - & - \\
percobaan & 200 & + & - & - \\
& 400 & + & - & - \\
& 800 & + & - & - \\
& 1.000 & + & - & - \\
& 1.500 & + & - & - \\
& 2.000 & + & - & - \\
& 3.000 & + & - & - \\
& 4.000 & + & - & - \\
\hline
\end{tabular}

Keterangan: Normositer: ukuran eritrosit sama dengan ukuran inti limfosit matur; Makrositer: ukuran eritrosit lebih besar daripada ukuran inti limfosit matur; Mikrositer: ukuran eritrosit lebih kecil daripada inti limfosit matur

alkaloid, senyawa ini diketahui dapat berinteraksi dengan membran eritrosit dan melakukan pore forming. Saponin adalah metabolit sekunder yang banyak didapatkan pada tanaman dan telah diketahui sebagai antimikrob. Hal ini sama halnya dengan alkaloid dan saponin juga dapat berinteraksi dengan membran eritrosit hingga membentuk lubang pada membran.7,8

Perubahan terhadap membran akan terdeteksi oleh reticuloendothelial system (RES) sebagai eritrosit yang abnormal sehingga dapat terjadi percepatan destruksi yang menyebabkan masa hidup eritrosit memendek. Kerusakan eritrosit mengakibatkan hemoglobin yang terdapat di dalamnya mengalami penurunan kadar (anemia). Kompensasi yang terjadi secara normal akibat terjadi anemia adalah peningkatan eritropoetin (Epo), yaitu hormon dengan massa molekuler

Tabel 4 Hasil Pengamatan Variasi Warna Eritrosit pada Sediaan Apus Darah Tepi

\begin{tabular}{|c|c|c|c|c|c|}
\hline \multirow{2}{*}{ Tikus } & \multirow{2}{*}{$\begin{array}{c}\text { Dosis p.o. } \\
\text { (mg/kgBB) }\end{array}$} & \multicolumn{3}{|c|}{ Variasi Warna } & \multirow[b]{2}{*}{ Polikrom } \\
\hline & & Normokrom & Hipokrom & Hiperkrom & \\
\hline - Kontrol & & + & - & - & - \\
\hline \multirow{10}{*}{$\begin{array}{l}\text { - Kelompok } \\
\text { percobaan }\end{array}$} & 50 & + & - & - & - \\
\hline & 200 & + & - & - & - \\
\hline & 400 & + & - & - & - \\
\hline & 800 & + & - & - & - \\
\hline & 1.000 & + & - & - & - \\
\hline & 1.500 & + & - & - & - \\
\hline & 2.000 & + & - & - & - \\
\hline & 3.000 & + & - & - & - \\
\hline & 4.000 & + & - & - & - \\
\hline & 5.000 & + & - & - & - \\
\hline
\end{tabular}

Keterangan: Normokrom: central pallor 1/3 ukuran sel; Hipokrom: central pallor $>1 / 3$ ukuran sel; Hiperkrom: central pallor $<1 / 3$ ukuran sel; Polikrom: eritrosit grey-blue 
31.0oo Dalton yang dihasilkan oleh kompleks peritubular ginjal yang merangsang prekursor eritroid di sumsum tulang. ${ }^{10}$

Eritropoesis merupakan proses pembentukan sel eritrosit yang diinduksi oleh eritropoetin. Eritropoesis berlangsung selama kira-kira 5 hari dengan perubahan berupa penurunan volume sel, penurunan rasio antara nuclear-cytoplasmic $(\mathrm{N}: \mathrm{C})$, kehilangan nukleoli, penurunan RNA sitoplasma dan mitokondria, serta juga terjadi peningkatan sintesis hemoglobin secara gradual. Akhir dari eritropoesis di sumsum tulang adalah pembentukan retikulosit, yaitu eritrosit imatur tidak berinti yang dilepaskan ke dalam sirkulasi dalam 2-3 hari dan berkembang menjadi eritrosit matur dalam 1-2 hari. ${ }^{10}$

Waktu penelitian yang singkat menjadi salah satu penyebab hasil pengamatan sediaan apus darah tepi menunjukkan hasil eritrosit normal mengingat retikulosit itu hanya membutuhkan waktu 1-2 hari untuk dapat berkembang menjadi eritrosit yang matur sehingga kekurangan jumlah eritrosit yang diakibatkan kerusakan membran masih dapat terkompensasi. Selain itu, toksisitas yang ditimbulkan oleh ekstrak air buah pepaya kemungkinan belum muncul dalam waktu 24 jam.

Keberagaman jenis kandungan yang terdapat di dalam suatu tumbuhan dapat menimbulkan interaksi biologi antarsenyawa kimia. Interaksi yang terjadi dapat merupakan interaksi positif atau interaksi yang negatif. Interaksi positif atau sinergis adalah interaksi antarkandungan yang saling menguatkan satu sama lainnya atau interaksi negatif atau antagonis, yaitu interaksi antarkandungan yang saling melemahkan satu sama lainnya. Keberagaman senyawa kimia di dalam buah pepaya (Carica papaya L.) muda dapat mengakibatkan interaksi antarsenyawa sehingga kandungan alkaloid dan saponin itu dapat menimbulkan disintegrasi membran pada eritrosit dapat dilemahkan oleh antioksidan tinggi dari flavanoid memiliki efek stabilitas membran dan antisickling dalam ekstrak sehingga tidak ditemukan perubahan morfologi eritrosit melalui pengamatan sediaan apus darah tepi.

Saponin mengakibatkan nekrosis pada selsel kanker dan hemolisis yang berkaitan dengan akumulasi ion kalsium intrasel sehingga terjadi kerusakan membran sel eritrosit itu. ${ }^{7}$ Penelitian yang dilaksanakan oleh Mahdeb dkk. ${ }^{8}$ mengenai efek hemolisis alkaloid yang ditentukan secara in vitro dengan mengukur absorbance $630 \mathrm{~nm}$ menggunakan 96 microwell plate menunjukkan bahwa peningkatan konsentrasi alkaloid pada hewan uji meningkatkan persentase hemolisis. Hasil penelitian ini tidak ditemukan gambaran eritrosit abnormal pada sediaan apus darah tepi menggunakan mikroskop cahaya. Perbedaan alat yang dipergunakan untuk mengamati parameter pada penelitian ini mungkin dapat menyebabkan perbedaan hasil antara penelitian saat ini dan penelitian terdahulu.

\section{Simpulan}

Tidak terdapat toksisitas akut ekstrak air buah pepaya atau Carica papaya L. muda terhadap morfologi sel eritrosit pada tikus putih (Rattus norvegicus) galur Wistar melalui pengamatan sediaan apus darah tepi.

\section{Ucapan Terima Kasih}

Terima kasih pada Kepala Bagian Patologi Klinik dan seluruh teknisi analis Laboratorium Patologi Klinik, Rumah Sakit Umum Daerah Cicalengka dan seluruh laboran di Laboratorium Biologi Medik, Fakultas Kedokteran, Universitas Islam Bandung yang telah membantu dalam rangkaian penelitian ini.

\section{Daftar Pustaka}

1. Rahmawati, Triyani Y, Nilapsari R. Biji cempedak (Artocarpus integrifolia) terhadap aktivitas fagositosis pada mencit jantan galur Swiss. GMHC. 2014;2(2):55-9.

2. Fathonah R, Indriyani A, Kharisma Y. Labu kuning (Cucurbita moschata Durch.) untuk penurunan kadar glukosa darah puasa pada tikus model diabetik. GMHC. 2014;2(1):2733 .

3. Dewoto HR. Pengembangan obat tradisional Indonesia menjadi fitofarmaka. MKI. 2007:57(7):205-11.

4. Iwuagwu M, Chukwuka KS, Uka UN. Evaluation of nutritional components of Carica papaya L. at different stages of ripening. J Pharmacy Biol Sci. 2013;6(4):136.

5. Kharisma Y, Ariyoga A, Sastramihardja HS. Efek ekstrak air buah pepaya (Carica papaya L.) muda terhadap gambaran histologi kelenjar mamma mencit laktasi. MKB. 2011;43(4):160-5. 
6. Aravind G, Bhowik D, Duraivel S, Harish G. Traditional and medicinal uses of carica papaya. J Med Plants Stud. 2013;1(1):7-15.

7. Bissinger R, Modicano P, Alzoubi K, Honisch S, Faggio C, Abed M, dkk. Effect of saponin on erythrocytes. Int J Hematol. 2014;100(1):519.

8. Mahdeb N, Mayouf S, Boukhari F, Souilah S, Bouzidi A. Hemolytic effect of total alkaloids from the seeds of Peganum harmala in vitro on erythrocytes of ruminants: sheep, cattle and goats. Asian J Plant Sci Res. 2013;3(6):53-9.

9. Badan Pengawas Obat dan Makanan Republik Indonesia. Pedoman uji toksisitas nonklinik secara in vivo. Jakarta: BPOM RI; 2014.

10. Harmening DM. Clinical hematology and fundamental of hemostasis. Edisi ke-5. Philadelphia: F.A. Davis Company; 2009.

11. Chinedu E, Arome D, Ameh FS. A new method for determining acute toxicity in animal models. Toxicol Int. 2013;20(3):224-6.

12. Nadiyah LD, Kharisma Y, Yuniarti. Penentuan derajat toksisitas akut ekstrak air buah pepaya (Carica papaya L.) muda pada mencit menggunakan purposed new recommended method. Jurnal Jamu Indonesia. 2016;1(2):15-9. 